\title{
THE TRADITION OF SNAKE-THREAD GLASS IN PANNONIA
}

\author{
KATA DÉVAI \\ Premium Postdoctoral Program of MTA \\ Eötvös Loránd University \\ 4/B, Múzeum körút, H-1088 Budapest, Hungary \\ kata.devai@gmail.com
}

\begin{abstract}
Snake-thread glass vessels were used from the late $2^{\text {nd }}$ to the mid- $3^{\text {rd }}$ century AD. At least two production centres/distribution circles have been identified in the western part of the Roman Empire, which probably owed their existence to Syrian glassmaking artisans migrating to the west. One was located in the Rhine region, the other in Pannonia. Considering the distribution of snake-thread glass fragments known to date from Pannonia, it is striking that 52 of the currently known 112 fragments were found at Intercisa, 45 exemplars came to light at Brigetio and only a few pieces are known from other sites. It is remarkable that in both towns, glass workshops were active during the same period and there is also some evidence that snake-thread glass had been produced in the workshop of Brigetio.
\end{abstract}

Keywords: snake-thread glass vessels, glass workshops, glass vessels with applied trails, immigrant glassworkers, Roman glass

The sophisticated decoration of snake-thread trails on beakers with stem and foot appeared in the $2^{\text {nd }}$ century AD, both in the eastern and western parts of the Roman Empire. According to D. Barag, this decorative technique had evolved from the barbotine technique, although this contention cannot be substantiated. ${ }^{1}$ A. Kisa was the first to devote special attention to this glass ware and to describe the types and decorative elements. ${ }^{2} \mathrm{D}$. B. Harden was the first to describe this type in 1934 based on finds from the eastern part of the Empire and he distinguished various groups. ${ }^{3}$ C. Isings described goblets on beaded stem from Cologne, Remagen and Karanis used in the late $2^{\text {nd }}$ to mid- $3^{\text {rd }}$ century AD (Form 86), ${ }^{4}$ and ovoid flasks on stemmed foot from Stein, Remagen and Cologne used during the same period (Form 93). ${ }^{5}$ Although the earliest workshop has not been identified yet, it was probably located in Syria. (Comparable material from Syria has been published by D. Barag. ${ }^{6}$ ) At least two production centres/distribution circles have been identified in the western part of the Empire, which probably owed their existence to Syrian glassmaking artisans migrating to the west. One was located in the Rhine region, probably in Cologne, the other in Pannonia. ${ }^{7}$ (There was possibly yet another one in northern Gaul, although the products of this workshop have a simpler decorative system than those produced in Cologne. ${ }^{8}$ ) A large number of snake-thread glass vessels with colourless or opaque blue with yellow applied trails are known from Belgium, but the trails are arranged into

Author's note: This study is part of my research project funded by the Premium postdoctoral fellowship programme of the Hungarian Academy of Sciences (working title: "Glass Vessels in Pannonia: Everyday Usage and Production from the First to Third Centuries A.D.”; ID number: 462032, host institution: ELTE-Eötvös Loránd University, H1088 Budapest, Múzeum krt 4/b). I am grateful to Sylvia Fünfschilling for kindly sharing her knowledge of Roman glass with me.

\footnotetext{
${ }^{1}$ BARAG 1967, 65.

${ }^{2}$ KISA $1899,58-66$

${ }^{3}$ HARDEN 1934, 50.

${ }^{4}$ ISINGS 1957, 103-104.

${ }^{5}$ IsINGS 1957, 110-111.

${ }^{6}$ BARAG 1967.

${ }^{7}$ STERN 2001, 138

${ }^{8}$ STERN 2001, 139.
} 
abstract patterns, stylised decorations, like on the beakers of the Cologne workshop. ${ }^{9}$ These fragments, found in the centre of Tongres, date from 170-180 to 250-260 AD. ${ }^{10}$ Some snake-thread glass vessels came to light in the northern Gaulish region, where this decoration type appeared not only on goblets, but also on bottles and plates. ${ }^{11}$ The products of the Cologne workshop were of outstanding quality, this being the reason that it was for long believed to have been the centre where this decorative technique was invented. ${ }^{12} \mathrm{~F}$. Fremersdorf suggested that eastern glassmaking artisans settling in Cologne began producing them. ${ }^{13}$ Some fragments decorated with looped serpentiform patterns are known from Britain from the late $2^{\text {nd }}$ to the early $3^{\text {rd }}$ century. ${ }^{14}$

In fact, there is a group of objects of eastern origin, but it remains unclear whether they originated directly from Syria or elsewhere. Harden noted that this type is considered to be of eastern origin, although we know far fewer pieces from the eastern Mediterranean than from the westerly regions of the Empire. ${ }^{15}$ Barag published nineteen vessels decorated with floral designs, birds, or birds and snakes. ${ }^{16}$

Fragments of different vessels found in Koi Dere (Bulgaria), Cyprus, Hanita (on the Phoenician coast), Carnuntum, Rome, Egypt, Cherson, Syria and Asia Minor can be assigned to this group. They are of very good quality and made of colourless materials, sometimes with a greenish hue. The colour of their decoration is usually identical. Two subgroups could be observed based on the decorative patterns: one of them features mostly patterns of leaves, the other one has not only purely ornamental, but also figural patterns such as bird motifs. One shared trait of the two groups is that the surface of the patterns was further decorated with chequered impressions using a tool. In view of the similarities in their raw materials, artistic quality, forms and decorations, they were clearly the products of the same workshop. Fragments of such vessels have been found across the entire eastern part of the Empire as well as along the Danube, in Pannonia and in Rome. ${ }^{17}$ Barag reconstructed the invention of the style and the manufacturing process as follows: The new decorative technique was invented in the east, possibly in Alexandria, in the late $2^{\text {nd }}$ century and the style continued to be made with chequer designs of Syro-Palestinian origin in the $3^{\text {rd }}$ century. ${ }^{18}$

Beakers with applied glass trail decoration in Pannonia have been analysed by L. Barkóczi, who classified them into four groups. ${ }^{19}$ The pieces in the first group are decorated with bird motifs, examples of which are known from Aquincum and Carnuntum; the second group comprises pieces decorated with tendrils and leaves, often with chequered surfaces and, less typically, with hemispherical or hexagonal (beehive) patterns (Fig. 1.2); the third category consists of pieces with slashed surfaces and no leaf motifs (Fig. 2.4); the fourth group includes fragments decorated with discontinuous patterns of upward-pointing leaves whose surfaces are slashed or imitated the veins of leaves (Fig. 2.5) ${ }^{20}$ Barkóczi published 67 snake-thread glass vessels altogether. The Pannonian finds are mostly goblets; only three globular flasks came to light at Intercisa, Savaria and Bakonyszentlászló. Although Barkóczi correctly identified the main motifs on these goblets, the range of combinations between the motifs on the known fragments remains unknown and it seems unwarranted to categorise the goblets into types based only on the main motifs. Therefore, in future studies, it is of prime importance to examine the combinations of these main motifs, to distinguish between monochrome and polychrome variants and, thirdly, to examine the surface of the motifs. The examination of the surfaces of motifs created with different tools (e.g. chequered surfaces, hemispherical or hexagonal patterns) can be of aid in identifying workshops and/or glassmaking artisans. According to Barkóczi, these types were most probably produced in Intercisa within a short time span at the beginning of the $3^{\text {rd }}$ century and the style arrived there either with the cohors I milliaria Hemesenorum and the Syrian glassmaking artisans migrating to Pannonia, or with the next wave of eastern immigrants during the reign of Alexander Severus. ${ }^{21} \mathrm{~A}$ glass workshop was uncovered at Intercisa $30 \mathrm{~m}$ south-west of the legionary fort in 1973. Five kilns and about $200 \mathrm{~kg}$ of glass batch were uncovered. This workshop probably remained active until the $260 \mathrm{~s} \mathrm{AD} .^{22}$

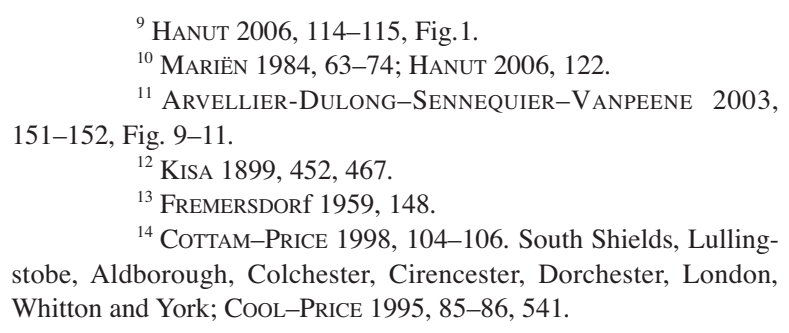

${ }^{14}$ CotTam-Price 1998, 104-106. South Shields, Lullingstobe, Aldborough, Colchester, Cirencester, Dorchester, London, Whitton and York; CoOL-PrICE 1995, 85-86, 541.

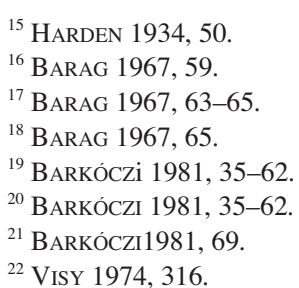

Acta Archaeologica Academiae Scientiarum Hungaricae 70, 2019 


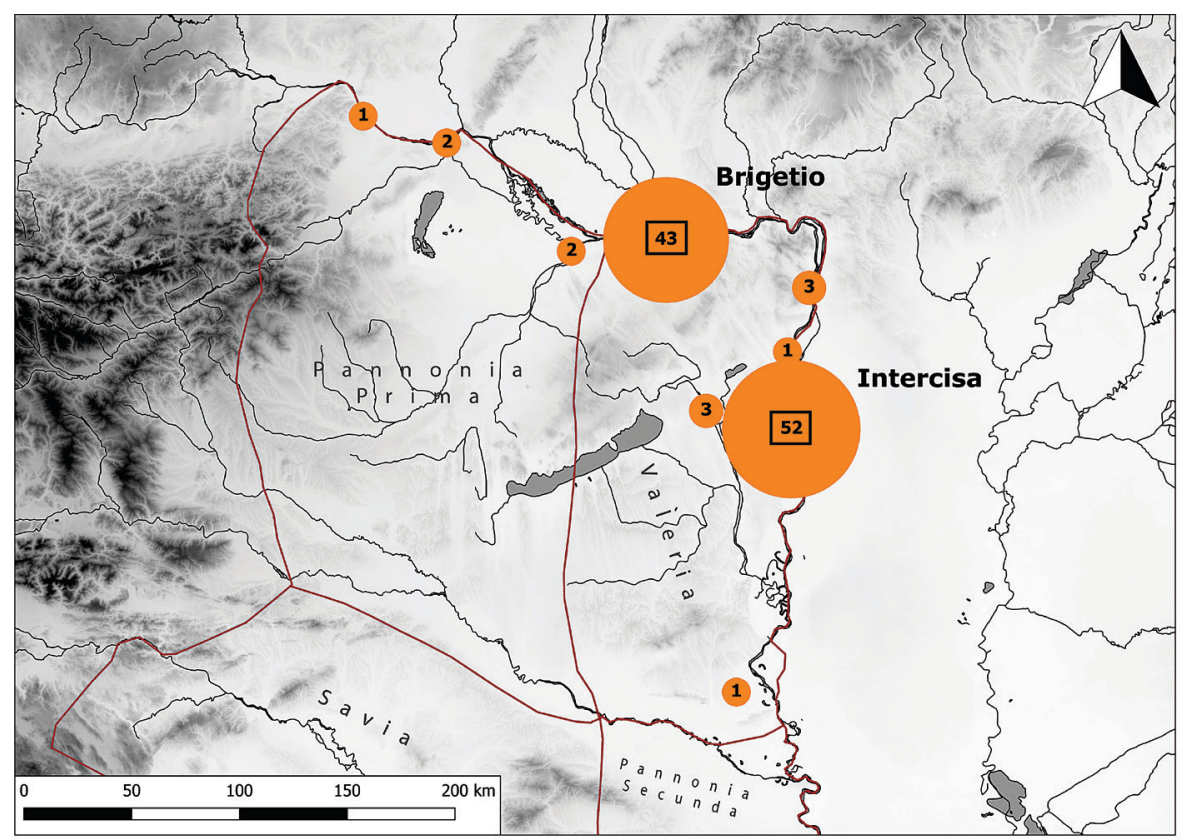

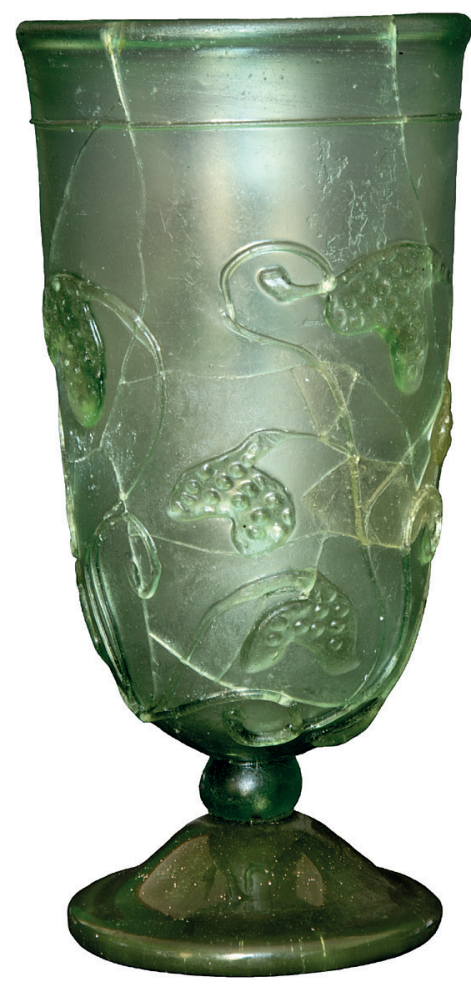

2.
1.

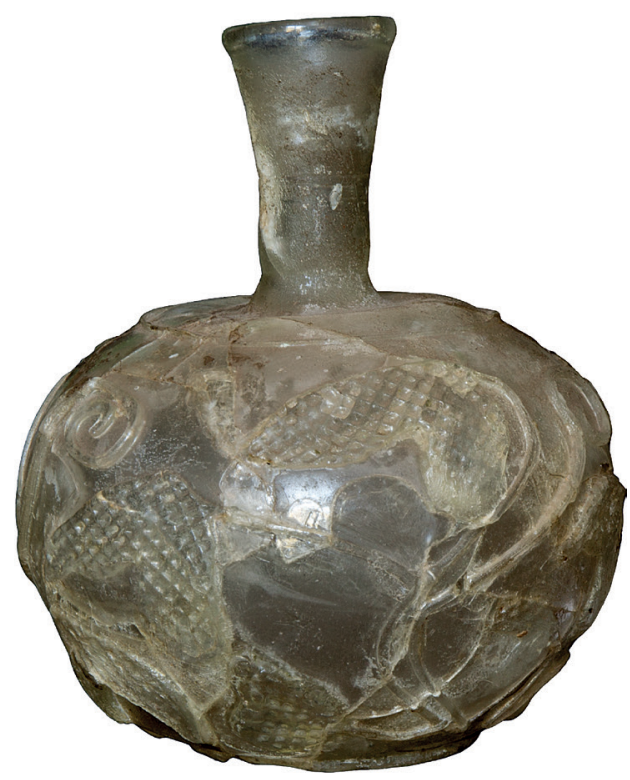

3.

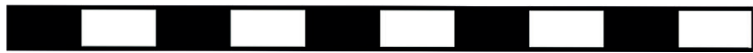

Fig. 1. 1: Distribution of snake-thread glass fragments in Pannonia (drawn by L. Rupnik); 2: Snake-thread goblets were decorated with tendrils and leaves. Intercisa Museum (photo: Tamás Keszi); 3: Bottle with snake-thread decoration. Intercisa Museum (photo: Tamás Keszi)

Acta Archaeologica Academiae Scientiarum Hungaricae 70, 2019 


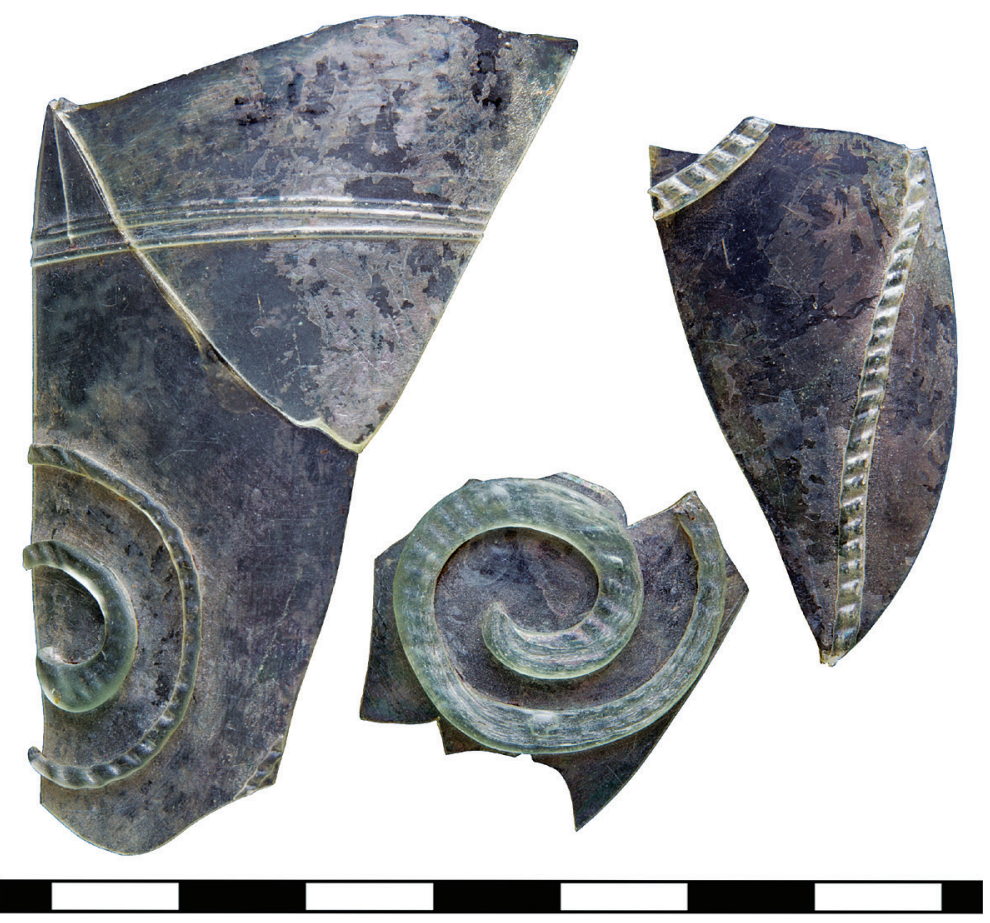

4.

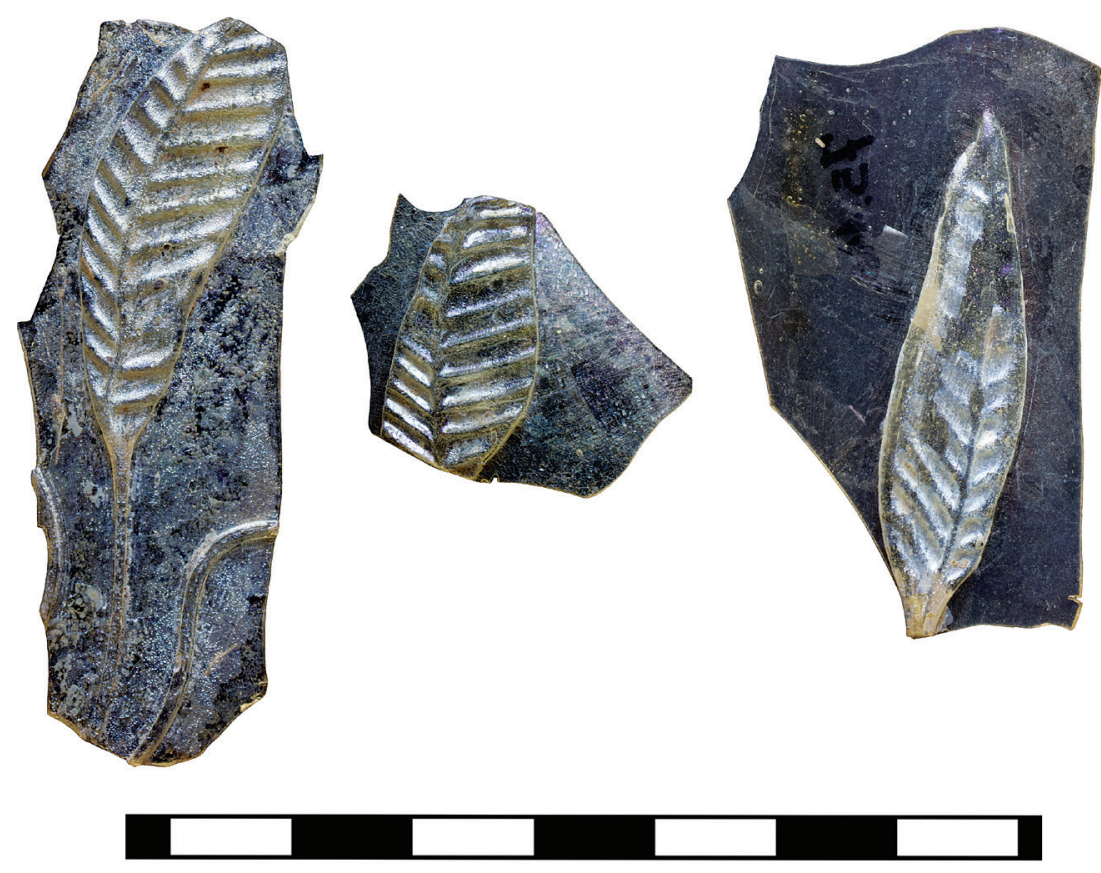

5.

Fig. 2. 4: Goblets were decorated with slashed surfaces, but no leaf motifs. Intercisa Museum (photo: Tamás Keszi); 5: Beakers were decorated with discontinuous patterns of leaves. Intercisa Museum (photo: Tamás Keszi) 
After the cohors I Aurelia Antoniniana milliaria Hemesenorum, a Syrian archer unit, was transferred to Intercisa, groups of eastern civilians came and settled there, and it seems likely that they had introduced the new glass style with applied trails, the so-called snake-thread glass in Pannonia. Eastern artisans were probably active in Brigetio as well. During the Severan period, there was a substantial oriental immigration to Pannonian towns, as part of the reconstruction programme after the Marcomannic Wars. ${ }^{23}$ The newcomers contributed significantly to the economic prosperity of the Danube provinces. ${ }^{24}$ In Pannonia, snake-thread beakers can be found primarily at Intercisa and Brigetio. Surveying the finds from other regions, particularly those parts of Pannonia that fall outside present-day Hungary, it would appear that the snake-thread beakers from Slavonia also fall into one of the four types distinguished by Barkóczi. ${ }^{25}$ The colourless glass pieces were decorated with bird motifs and ornamental patterns, and occasionally dolphin figures. ${ }^{26}$ Based on fragments from the cemetery of Poetovio, they can similarly be dated to the earlier $3^{\text {rd }}$ century A.D. ${ }^{27}$ Fragments from Vindobona also fit into the categories distinguished and described by Barkóczi. ${ }^{28}$

\section{SNAKE-THREAD GLASS FRAGMENTS FROM BRIGETIO}

Below, I shall discuss the snake-thread glass fragments found in the municipium of Brigetio (Figs 4.9-12, Figs 5.13-27, Figs 6.28-45, Figs 7.46-47, Figs 8.48-60).

In terms of archaeological research, the civil town is the least known of the three main urban areas of Brigetio (the civil town, the legionary fortress and the canabae). It is located in a suburban area of KomáromSzőny and its area is now mostly built up, except for the Vásártér area (the town's market place during the Early Modern Age). ${ }^{29}$

The 25 years of research excavations at Komárom/Szőny-Vásártér, in the heart of the civil town of Brigetio, have come to an end. ${ }^{30}$ We now have a rough picture of the general time frame and building phases of the town, ${ }^{31}$ providing an excellent framework for the systematic assessment of the characteristic finds such as the fragments of so-called "Schlangenfaden Glas”.

\section{MAIN CHARACTERISTICS}

All fragments come from cylindrical beakers with stem and foot. They have a slightly out-turned rim with fire-rounded edge, they are tall and narrow with solid globular stem and wide foot with fire-rounded edge. The foot was blown separately, the stem is narrow, short and cylindrical, occasionally with a globular knob.

The vessels are generally colourless or greenish. The decorative design consists of the following elements: self-coloured trails below the rim and on the base, looped serpentiform motifs, vertical trails occasionally folded over each other, leaves with stamped chequered and spherical motifs, and tendrils with slashed surface. The trails are either self-coloured or have opaque whitish, yellowish or bluish hues.

A total of seventeen glass fragments were found between 1992 and 2005, all of which were made of goodquality glass. The glass material used for their decoration was identical. Many have a leaf decoration with chequered surface as well as tendril motifs with slashed surface. One such fragment was found during the 2010 excavation season $^{32}$ and four more were brought to light in 2012. ${ }^{33}$ The colourless fragments are decorated with colourless threads forming tendrils and leaf motifs applied to their surface. The surfaces of the tendrils were slashed and the leaves were stamped with spherical motifs. According to Barkóczi's aforementioned classification system, these fragments can be assigned to his Groups II and III. ${ }^{34}$ The high number of fragments clearly attests to the use of snake-thread beakers in the civil town of Brigetio for a short period of time at the beginning of the $3^{\text {rd }}$ century.

${ }^{23}$ Mócsy 1974, 227.

${ }^{24}$ MÓCSY 1974, 227.

${ }^{25}$ LAZAR 2003, 115-116, Type 3.8.4.

${ }^{26}$ LAZAR 2003, 116.

${ }^{27}$ LAZAR 2003, 116.

${ }^{28}$ SAKL-OBERTHALER-TARCSAY 2001, 92, Taf. 4.34a-b.

${ }^{29}$ DoBOSI-BORHY 2011, 5.
${ }^{30}$ The research excavations led by Emese Számadó, director of the Klapka György Museum of Komárom, and László Borhy, rector of Eötvös Loránd University, were carried out between 1992 and 2016.

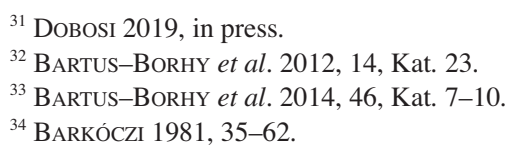

Acta Archaeologica Academiae Scientiarum Hungaricae 70, 2019 


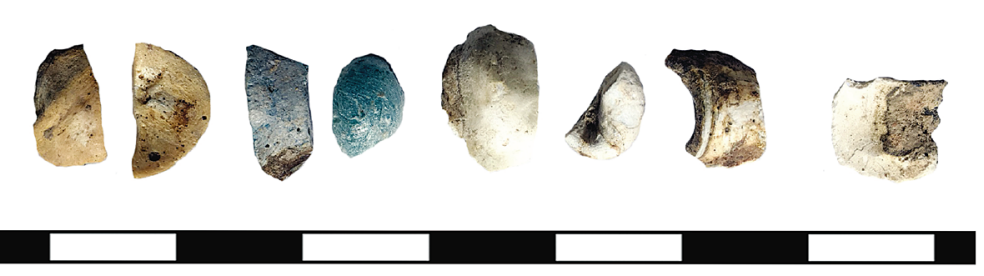

6.

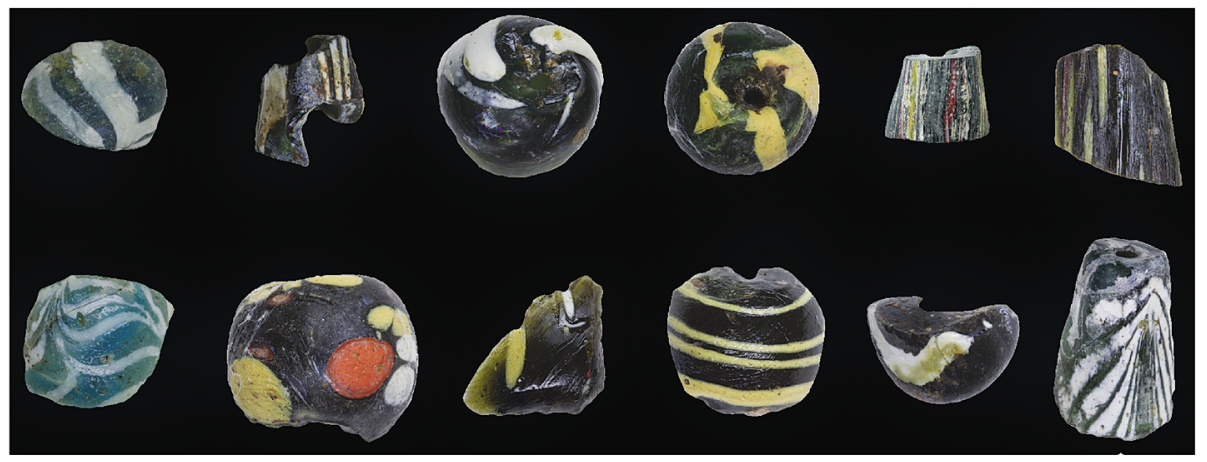

7.
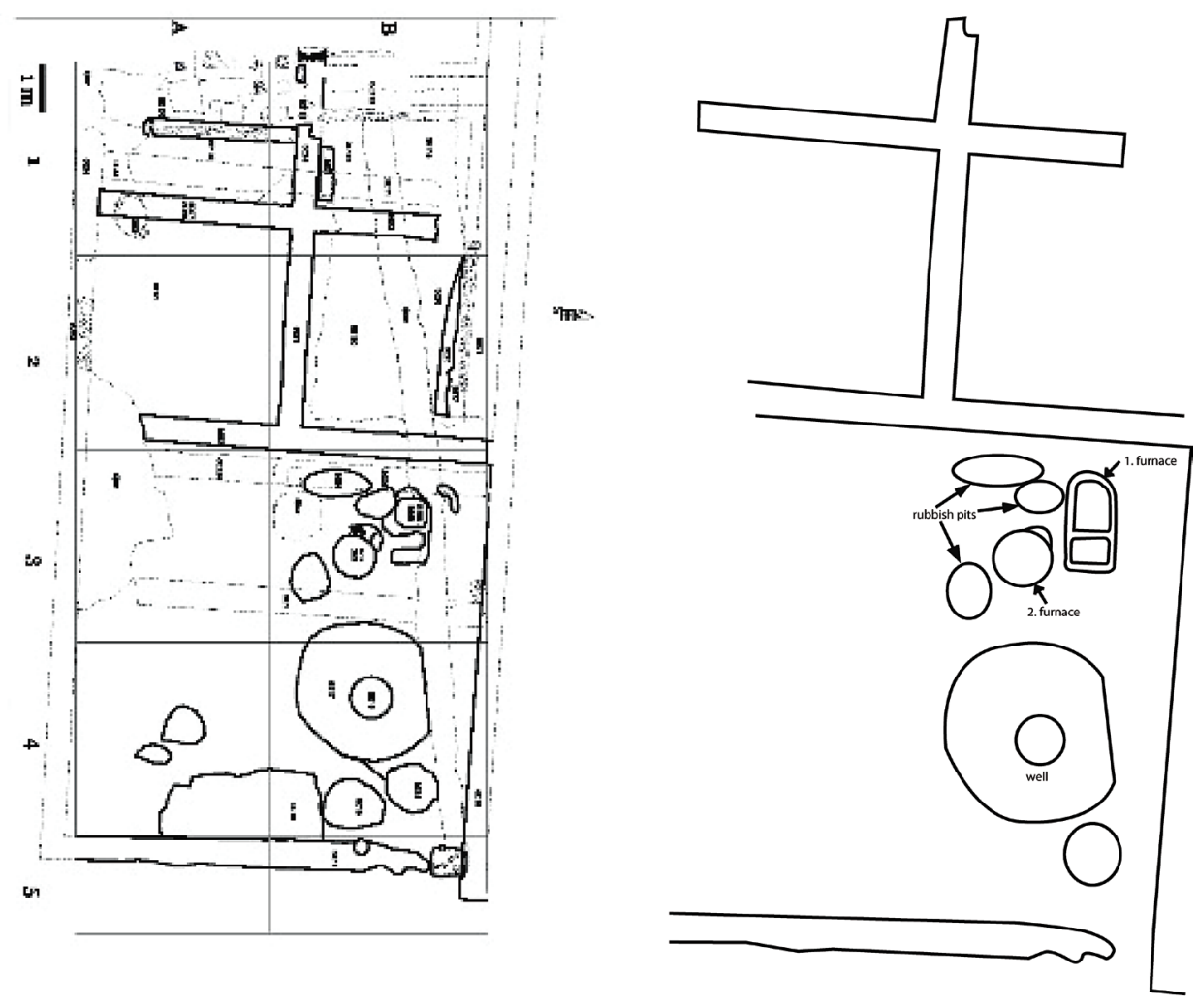

8.

Fig. 3. 6: Colouring additives from the glass workshop in Brigetio;

7: Glass beads from the glass workshop in Brigetio; 8: Glass workshop in Brigetio (photo: Ákos Gelencsér) Acta Archaeologica Academiae Scientiarum Hungaricae 70, 2019 


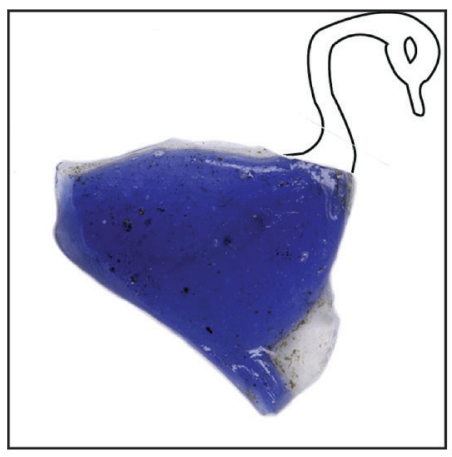

9.
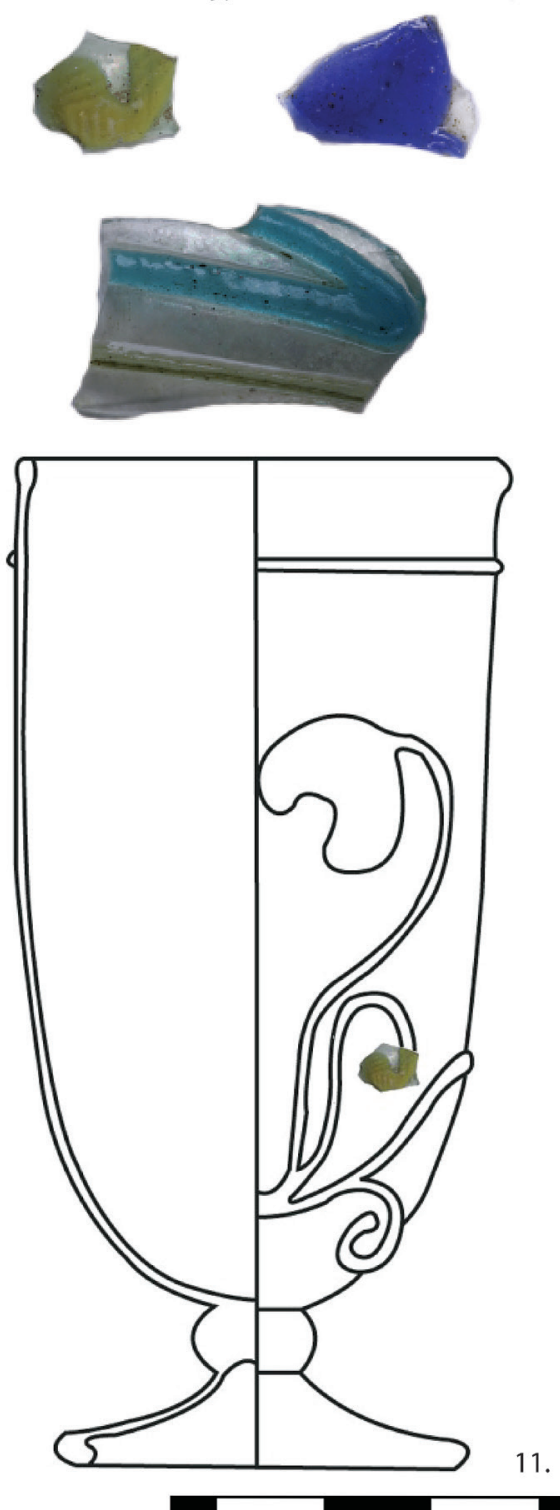

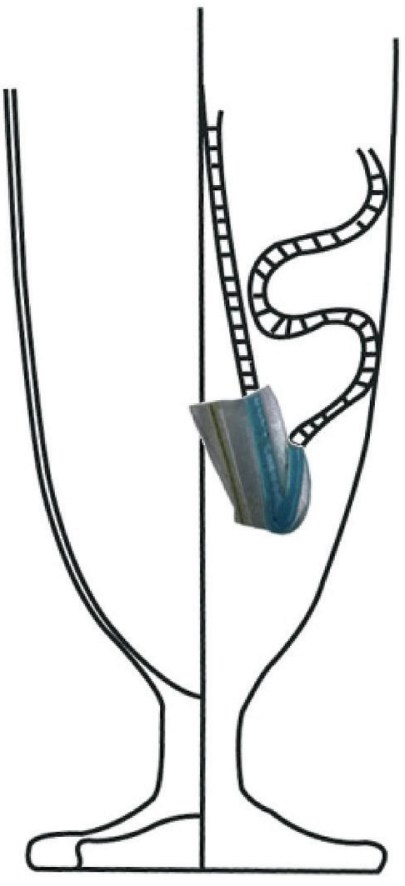

10.

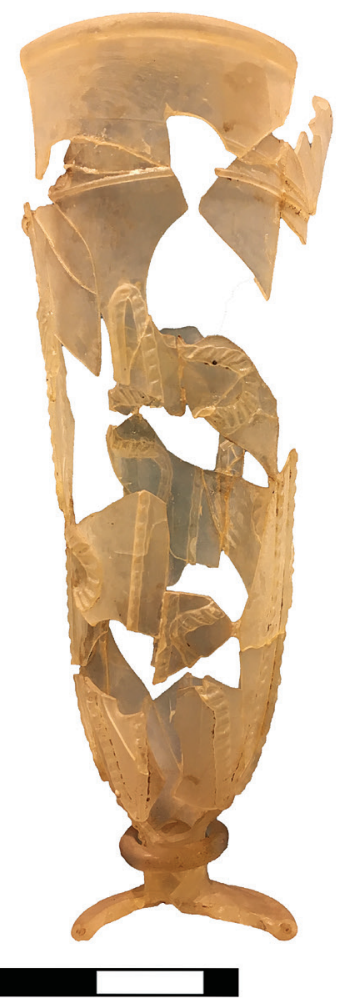

12.

Fig. 4. 9-11: Fragments of snake-thread goblets from Brigetio. 9: Cat. no. 45; 10: Cat. no. 29; 11: Cat. no. 26; 12: Goblet with snake-thread decoration: trails with slashed surface. Intercisa Museum

Acta Archaeologica Academiae Scientiarum Hungaricae 70, 2019 


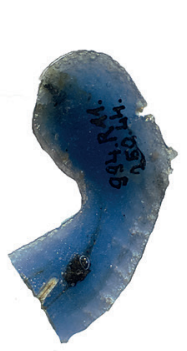

13.

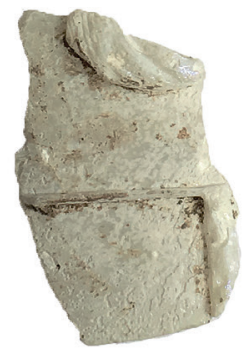

14.

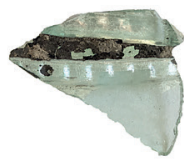

17.

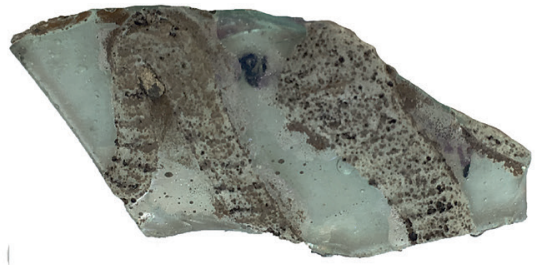

15.

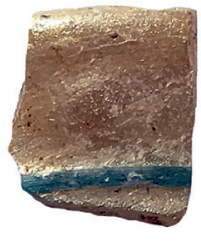

18.

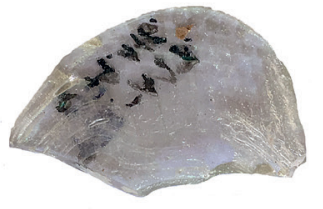

21.

19.

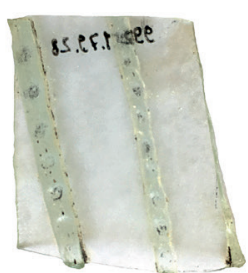

23.

22

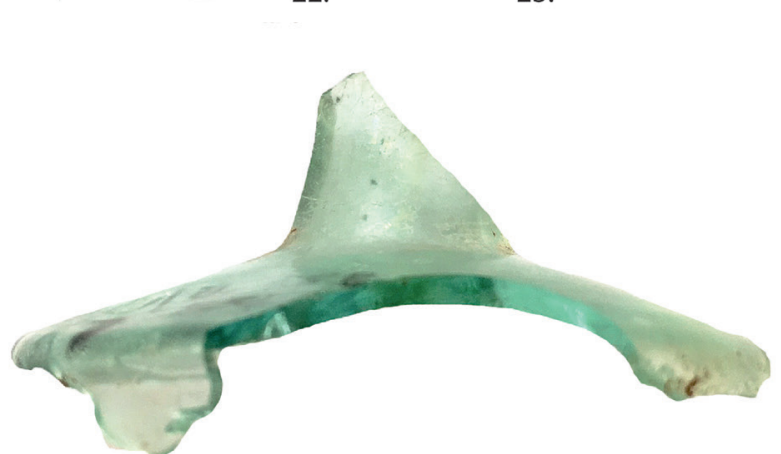

26.

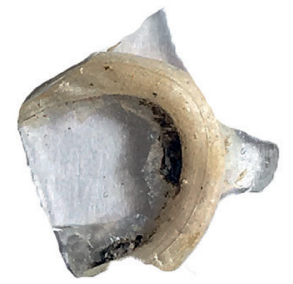

24.

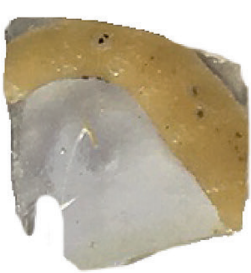

25.

27.
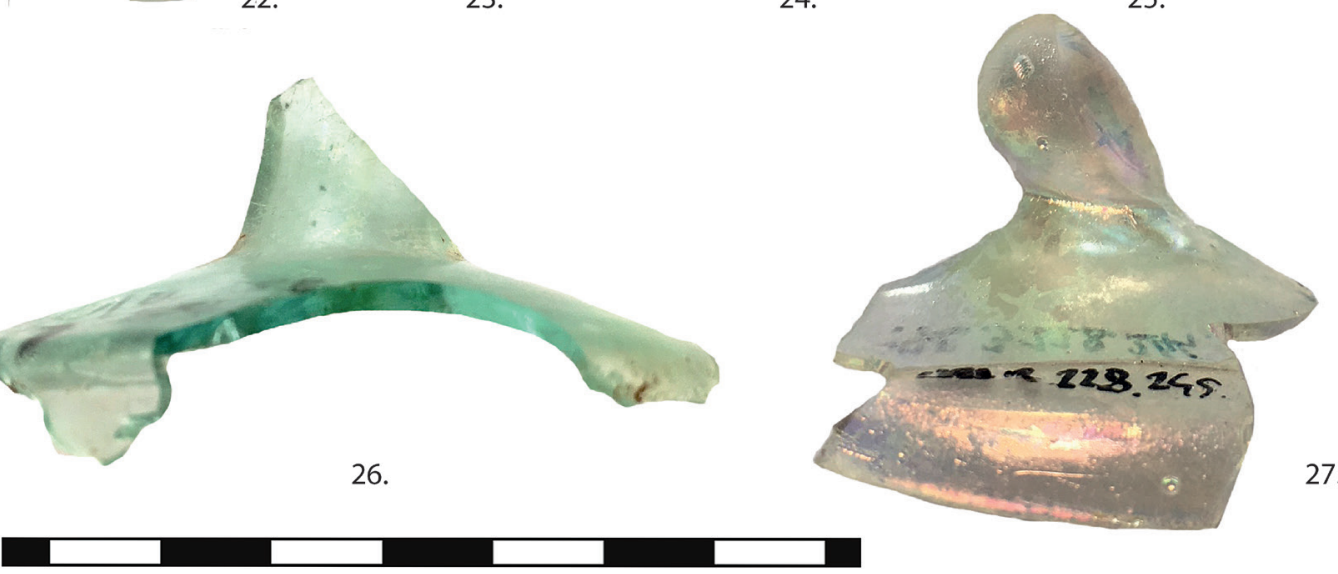

Fig. 5. 13-27 Fragments of cylindrical beakers with stem and foot from Brigetio. 13: Cat. no. 6; 14: Cat. no. 38; 15: Cat. no 12; 16: Cat. no. 25; 17: Cat. no. 28; 18: Cat. no. 36; 19: Cat. no. 27; 20: Cat. no. 26; 21: Cat. no. 1; 22: Cat. no. 5; 23: Cat. no. $14 ; 24$ : Cat. no. $37 ; 25$ : Cat. no. $31 ; 26$ : Cat. no. 7 ; 27 : Cat. no. 16 


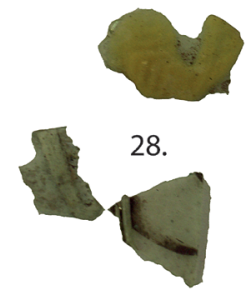

29.

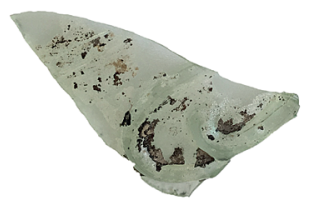

31.

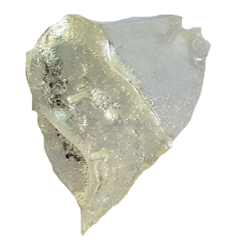

35.

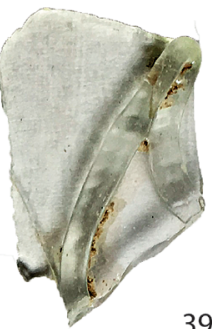

39.

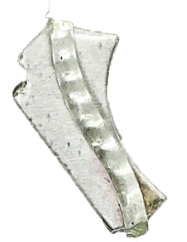

40.

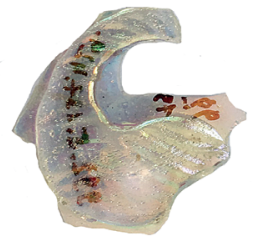

36.

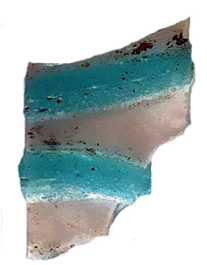

42.
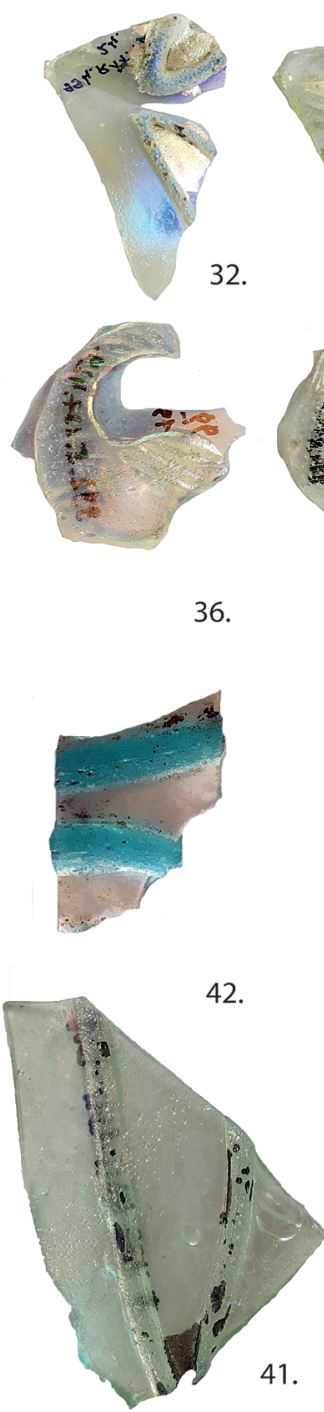

32.

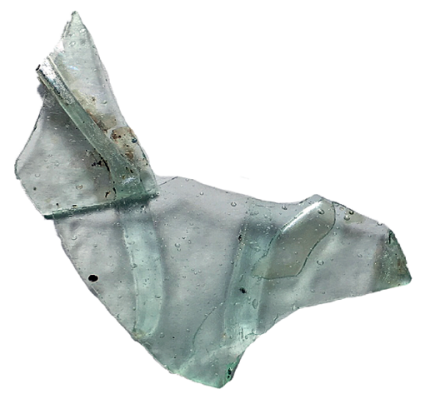

30.

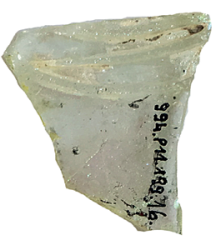

33.

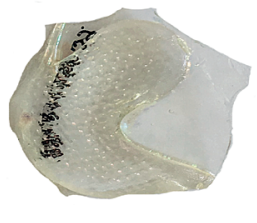

37.
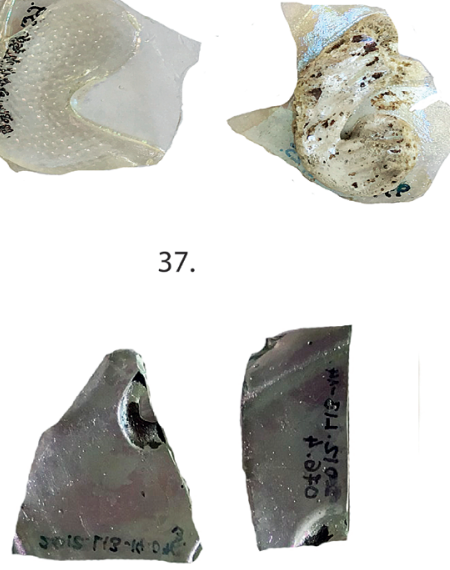

43.

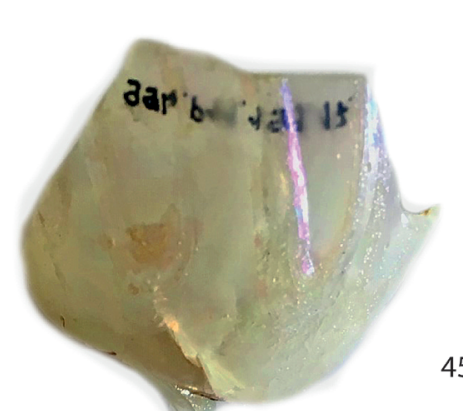

38.

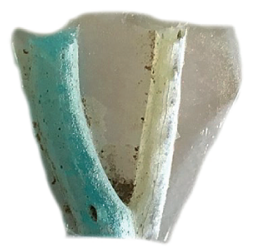

44.

45.

Fig. 6. 28-45: Fragments of snake-thread glass vessels from Brigetio. 28: Cat. no. 40; 29: Cat. no. 32; 30: Cat. no. 42; 31: Cat. no. 13; 32: Cat. no. 3; 33: Cat. no. 15; 34: Cat. no. 10; 35: Cat. no. 9; 36: Cat. no. 4; 37: Cat. no. 8; 38: Cat. no. 11; 39: Cat. no. 34; 40: Cat. no. 35; 41: Cat. no. $41 ; 42$ : Cat. no. $30 ; 43$ : Cat. no. $19 ; 44$ : Cat. no. $43 ; 45$ : Cat. no. 2 


\section{A WORKSHOP IN BRIGETIO AND ITS CONNECTION WITH SNAKE-THREAD GLASS VESSELS}

In 2006, the Klapka György Museum of Komárom together with the Institute of Archaeological Sciences of Eötvös Loránd University undertook an excavation in the less researched area of the civil town of Brigetio, at 13 Vásártér, Komárom/Szőny. During the excavation of a $153 \mathrm{~m}^{2}$ large area, the living quarters of a strip-house with various construction phases and a glass workshop associated with one of these phases were discovered. The building had five construction periods and a secondary glass workshop associated with one of these. The remains of two kilns were found in the workshop (Fig. 3.8). ${ }^{35}$

Four pits were uncovered around the remains of two glass kilns in the back yard of a house (Fig. 3.8): one of the pits contained all the glass beads that were found during the excavation - both wasters and intact pieces -, while the other three contained molten glass drops, debris, production waste, raw glass fragments, additives, pieces of glass sticks and glass threads, some of which had tool marks on their surfaces. Fragments of vessels and glass window panes were also found. As fragments of broken glass objects were systematically collected and recycled in the Roman period, the recovered finds were not necessarily produced by the local workshop. (Further studies are needed to determine whether, in addition to the wasters and raw glass materials, a part of the material came from elsewhere or was collected locally for recycling.) It is certain that the beads, most of which were wasters except for eight intact pieces, were produced locally. The material of the raw glass pieces found in the refuse pits is identical to what most of the beads were made of. Moreover, the colour of some small glass lumps is identical to that of the beads' decoration. Thus, one may conclude that they were produced in this workshop. Since the forms, colours, and decorations of the beads found in various graves in Brigetio are similar to these, one may justifiably argue that the workshop's products were primarily intended for the population of the civil town and the canabae. At the same time, the question remains of whether the workshop, which was active for a short time only, was solely engaged in the mass production of beads, or whether it also produced glass vessels and glass window panes as well.

One hundred and twenty-one in part fragmentary and in part intact beads (Fig. 3.7), and several vessel and window pane fragments were recovered from the pits. ${ }^{36}$ Some cylindrical beakers with flower and bird motifs of Syrian origin were also brought to light. Different colours appear on their colourless body, ranging from colourless trails to opaque yellow or white and blue ones (Figs 4.9-11). The same white and yellow can be seen on the decoration of the beads. Some other white and yellow coloured glass lumps assumed to be colouring additives were also found. The same colouring additives and the same colours dominate the decoration of both the beads and the cylindrical goblets with serpentiform trails, indicating the production of this type in the workshop (Figs 3.6-7). Thus, there is some evidence that snake-thread glass wares were produced in this workshop. Many fragments of Syrian beakers came to light from the refuse pit and the glass furnace. Over twenty small snake-thread beaker fragments come directly from the workshop, alongside the colouring agents used during their manufacture (the use of these colours can be clearly seen on both the beads and the snake-thread beakers) (Figs 3.6-7).

The glass workshop in Brigetio operated within the borders of the civil town (intra muros) for a brief period. Both glass beads and vessels were made in the two kilns, which could have been a circular melting kiln with an attached lehr.

The site of the glass workshop excavated at 13 Vásártér Square during a small rescue excavation is located immediately beside the main research excavation location of the Vásártér site. The excavation took place prior to the construction of a house. Most of the glass vessel fragments and all the glass beads were found in refuse pits beside the glass kilns. The fragments of snake-thread cylindrical beakers with stem and foot were found in the kiln (SE 58) as well as in the fill of the refuse pits beside it (SE 14, SE 15, SE 16).

The colourless body fragments are decorated with opaque (yellowish), white and turquoise blue threads. ${ }^{37}$ The beads have similar decorations. Small white, yellow and blue chunks of colouring agents were found (Fig. 3.7), suggesting that the beakers were produced locally. Another proof for the local production of vessels is that one of the kilns was probably used as a cooling kiln. Had the glass beads contained copper as a colouring agent for red colour, they would have had to be cooled in this kiln. However, since only a few beads of this type were found, the

${ }^{35}$ DÉvai-Gelencsér 2012, 59-93; DÉvai 2015, 83-104.
${ }^{36}$ DÉvai-GElencsér 2012, 59-93; DÉvai 2015, 83-104.

Acta Archaeologica Academiae Scientiarum Hungaricae 70, 2019
${ }^{37}$ They were made of colourless glass and decorated with colourless, yellow, dark blue and turquoise blue tendril patterns. The surface of the tendrils is slashed. One fragment is decorated with a bird motif whose surface is chequered and has a dark blue-opaque colour. 

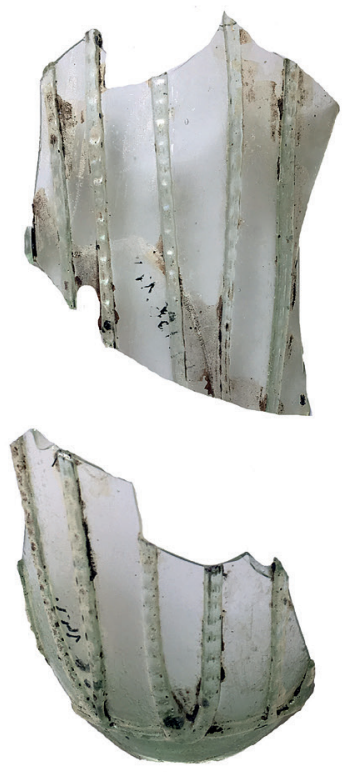

46.
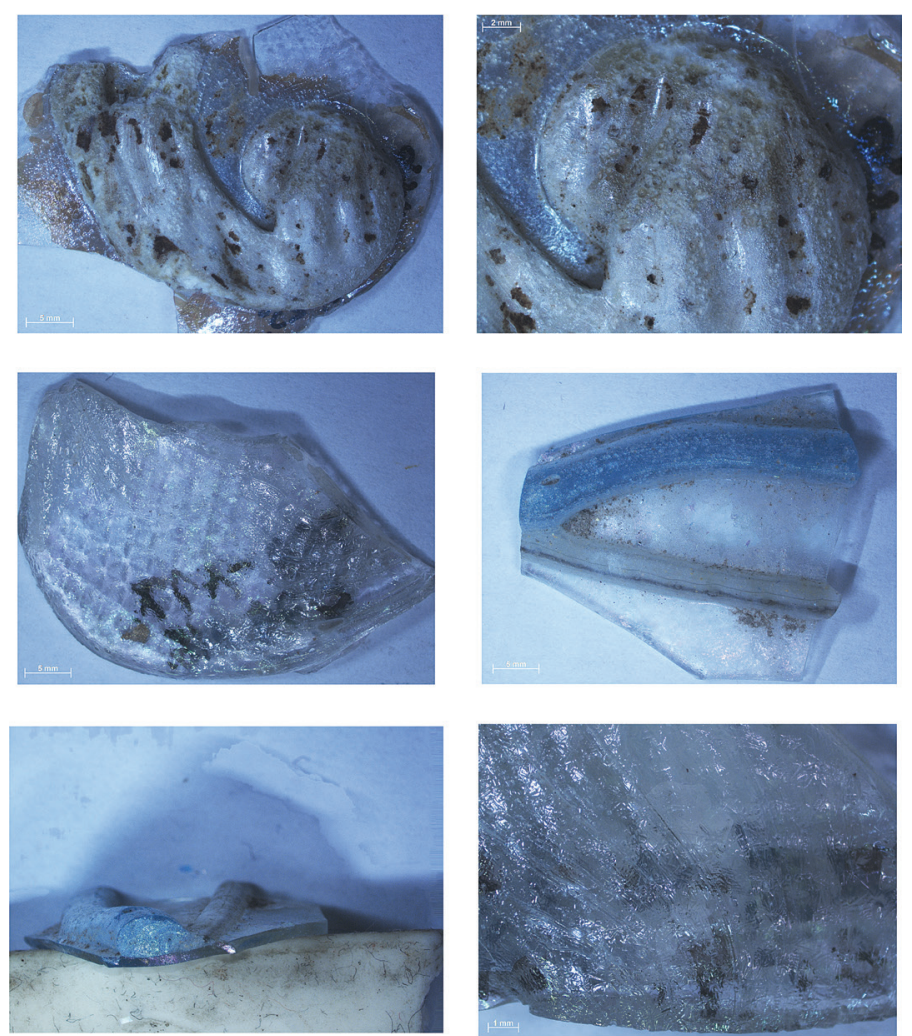

47.

Fig. 7. 46: Fragment of a snake-thread glass vessel from Brigetio, Cat. no. 17; 47: Fragments of snake-thread glass beakers. Optical microscopic examinations (Zeiss SteREO Discovery V.8 zoom-stereomicroscope, Archaeometry Laboratory of the ELTE, funded by Grant KMOP-4.2.1/B-10-2011-0002; micrographs: ZEISS AxioCam MRc5; ZEISS AxioVision version 4.9.1 software; extended focus system images: Helicon Focus version 6.0) 


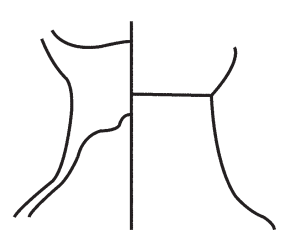

48.

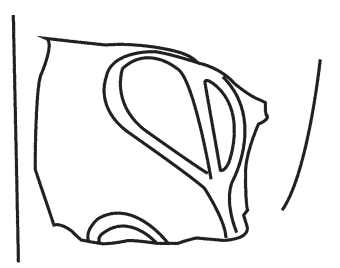

49.

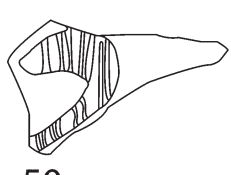

50.

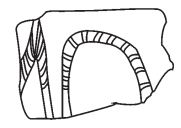

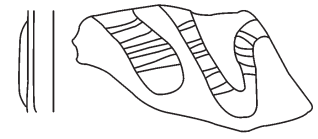

51.

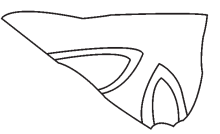

55.

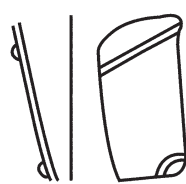

57.

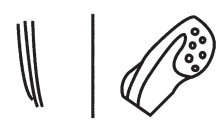

59.

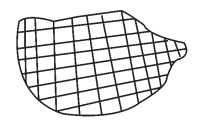

52.
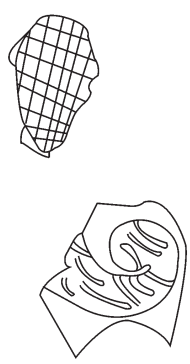

56.

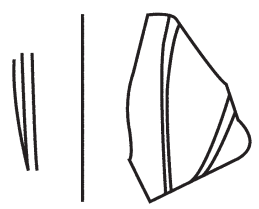

58

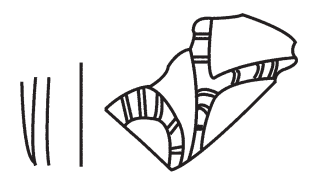

60.

Fig. 8. 48-60: Fragments of snake thread glass vessels from Brigetio. 48: Cat. no. 23; 49: Cat. no. 24; 50: Cat. no. 13; 51: Cat. no. 12; 52: Cat. no. 44; 53: Cat. no. 4; 54: Cat. no. 18; 55: Cat. no. 3; 56: Cat. no. 11; 57: Cat. no. 19; 58: Cat. no. 20; 59: Cat. no. 21; 60: Cat. no. 22 Acta Archaeologica Academiae Scientiarum Hungaricae 70, 2019 
kiln must have served for producing vessels instead. Thus, one may conclude that the vessels were made in Brigetio too. They are decorated with snake-threads applied to the surface in a particularly fine manner, and they constitute a group that is not fully identical with that of other beakers found in the main excavation area, given that mostly colourless glass was used for their decoration.

It seems prudent to explore the origins and distribution of snake-thread beakers. It seems to me that the Pannonian material, including the finds from the main Vásártér site in Brigetio/Szőny and the rescue excavation at 13 Vásártér Square, represents the group identified by Barag. They can be dated to the beginning of the $3^{\text {rd }}$ century $\mathrm{AD}$; they are of eastern origin and their artistic quality is without doubt quite outstanding. Whether the style evolved in Syria (as it very likely did) calls for further studies. It is certainly different from the "western" Cologne style.

It is particularly interesting that in Pannonia, snake-thread beakers have principally been found in settlement contexts (examples are known from Brigetio and Intercisa), and it would appear that they were not deposited in burials. There is evidence for glass workshops operating in both towns. The Pannonian finds are mostly cylindrical beakers with stem and foot, only three globular bottles are known (from Intercisa, Savaria and Bakonyszentlászló) (Fig. 1.3). Considering the distribution of snake-thread glass fragments known to date from Pannonia, it is striking that 52 of the currently known 112 fragments were found at Intercisa (Figs 1.2-3, Figs 4-5), 45 pieces came to light at Brigetio (Figs 4.9-12, Figs 5.13-27, Figs 6.28-45, Figs 7.46-47, Figs 8.48-60) and only a few pieces are known from other sites (three each from Aquincum and Gorsium, two each from Carnuntum and Aquincum, and one whit each from Vindobona, Matrica and Majs alongside an unprovenanced piece) (Fig. 1.1). A new find must here be mentioned from Savaria, where 110 graves of the northern cemetery were excavated by P. Kiss in $2006 .{ }^{38}$ The investigated cemetery section was used from the later $1^{\text {st }}$ century to the end of $2^{\text {nd }}$ century $\mathrm{AD}$. Among the grave goods of one of the cremation burials roofed with tiles was a glass bottle with applied base ring and snakethread decoration. The colourless globular flask is decorated with self-coloured slender spiral tendrils ending in leaves and the figure of a bird. The surface of the leaves and the bird is decorated with chequered impressions. The other grave goods of Grave 38 were a square bottle, two other globular flasks, a square, indented flask, a pear-shaped jar and two conical unguent bottles. ${ }^{39}$ This seems to be particularly interesting and calls for further studies because no snake-thread glass vessels have yet been found in Pannonian burials and its date is too early.

At Intercisa, five glass kilns as well as 220 kilograms of waste (raw glass, molten glass and semi-finished

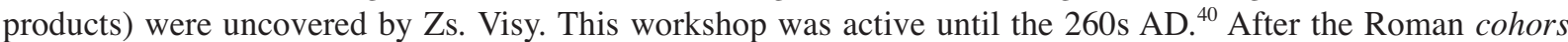
I Aurelia Antoniniana milliaria Hemesenorum was transferred to Intercisa, a high number of civil settlers probably arrived in several successive waves from the recruitment area. On the testimony of the grave inscriptions and the personal names, a large number of people of eastern origin settled in the canabae of Intercisa, to whom we may attribute the introduction of glassmaking in Pannonia. As we have seen, this was the very period when the first snake-thread beakers appeared in Brigetio and when the production of similar beakers in the Brigetio workshop started. Thus, one may tentatively conclude that Intercisa and Brigetio were the major production centres of snakethread beakers in Pannonia, and that the activity of these workshops was connected to glassmaking artisans migrating here from the east. The Pannonian finds form a coherent assemblage ${ }^{41}$ representing a short time period of 25 to 30 years, either after the Marcomannic Wars or, more likely, between 230 and 260, during the reign of Alexander Severus, which saw the arrival and settlement of a new wave of eastern immigrants. The glass trails are often decorated with spherical and beehive-like patterns, stamped on their surface, a practice that is attested in Syria, but does not seem to have reached Cologne. In sum, these decorative patterns and techniques were most probably brought to Pannonia by the eastern glassmaking artisans active in the Brigetio and Intercisa workshops at the beginning of the $3^{\text {rd }}$ century. Based on the currently known fragments, we may assert that the discontinuous patterns of upwardpointing leaves with veins is known only at Intercisa, where the widest range of both monochrome and polychrome patterns were also employed: bird-shaped and ornamental motifs, spiral trails with smooth surface, tendrils and

${ }^{38}$ KISs 2006, 93.

${ }^{39}$ KISS 2007.

${ }^{40}$ VISY 1974, 316.

${ }^{41}$ Taking into account only the Pannoninan decoration types and their possible combinations; cf. BARKóczI 1981. The style of the beakers found in Pannonia clearly differs from that of the finds from Cologne. The Cologne workshop is probably earlier and can be associated with glassmaking artisans, who had settled there during the time of Marcus Aurelius. While the Pannonian finds are mostly beakers with stem and foot, applied decorations were used on various types of vessels in Cologne. The shape of the leaves and the structure of the motifs are different on the Pannonian finds, whereas on the Cologne finds, the surfaces of the leaves were not impressed with chequered or beehive patterns, and the slashed decoration as well as large-leaved tendrils - typical for the Pannonian ones - are also missing. 
leaves with chequered or hemispherical design, and tendrils with slashed surface. A smaller variety of patterns was observed at Brigetio, where the following patterns are not attested: discontinuous leaves the chequered design of leaves and the monochrome bird pattern. Ornamental motifs with smooth surfaces in both monochrome and polychrome, tendrils with slashed surfaces and leaves with hemispherical patterns are attested in very high numbers. The tooled decoration of the surface is mainly characteristic of colourless glass trails, although not exclusively. One interesting question is whether monochrome and polychrome wares were produced simultaneously or in different periods. In Brigetio, polychrome decoration is common in the glass workshop, while monochrome variants dominate the finds from the Vásártér site. It should be noted that both polychrome and colourless trails can be observed on certain fragments, indicating that these are unlikely to date from separate periods. 


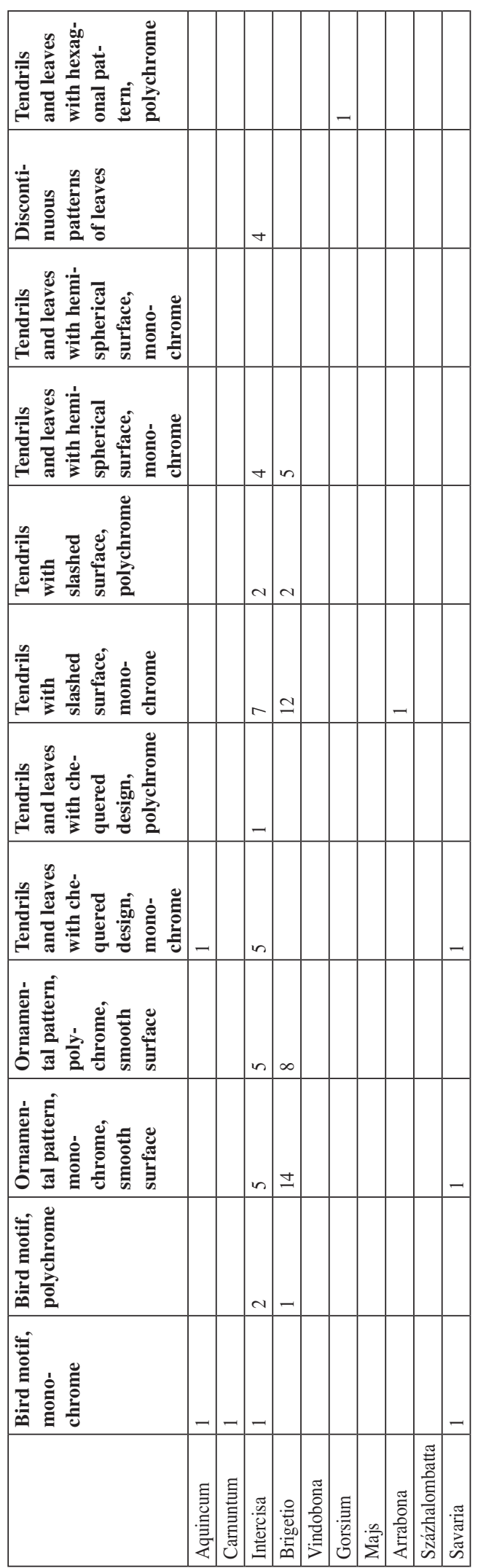

Acta Archaeologica Academiae Scientiarum Hungaricae 70, 2019 


\section{CATALOGUE}

1. Brigetio/Szőny-Vásártér: Inv. no. 1994.-B13.72.9, fragment of a cylindrical beaker, colourless; decoration: self-coloured leaf fragment (Fig. 5.21)

2. Brigetio/Szőny-Vásártér: Inv. no. 1994.P11.199.17, base fragment of a cylindrical beaker, tapering lower body with globular knob on the stem, colourless; decoration: self-coloured looped serpentiform vertical V-shaped trails (Fig. 6.45)

3. Brigetio/Szőny-Vásártér: Inv. no. 1994.R11.098.24, fragment of a cylindrical beaker, colourless; decoration: opaque blue looped serpentiform vertical trails (Fig. 6.32, Fig. 8.55)

4. Brigetio/Szőny-Vásártér: Inv. no. 1994.R11.198.26, fragment of a cylindrical beaker, colourless; decoration: self-coloured looped serpentiform vertical trails (Fig. 6.36, Fig. 8.53)

5. Brigetio/Szőny-Vásártér: Inv. no. 1994.R11.250.31, fragment of a cylindrical beaker, colourless; decoration: self-coloured looped serpentiform vertical trails (Fig. 5.22)

6. Brigetio/Szőny-Vásártér: Inv. no. 1994.R11.250.44, fragment of a cylindrical beaker, colourless; decoration: opaque dark blue curved tendril fragment with thick rounded end (Fig. 5.13)

7. Brigetio/Szőny-Vásártér: Inv. no. 1993.E13.007.5, fragment of a cylindrical beaker with stem and foot, greenish, base fragment (Fig. 5.26)

8. Brigetio/Szőny-Vásártér: Inv. no. 1994.P11.250.38-39, fragment of a cylindrical beaker, colourless; decoration: self-coloured heart-shaped leaf motif with hemispherical patterns (Fig. 6.37)

9. Brigetio/Szőny-Vásártér: Inv. no. 1994.P11.250.40, fragment of a cylindrical beaker, colourless; decoration: self-coloured leaf motif with hemispherical patterns (Fig. 6.35)

10. Brigetio/Szőny-Vásártér: Inv. no. 1994.P11.250.41, fragment of a cylindrical beaker, colourless; decoration: self-coloured looped serpentiform vertical V-shaped trail (Fig. 6.34)

11. Brigetio/Szőny-Vásártér: Inv. no. 1998.-A17.74.116, fragment of a cylindrical beaker, colourless; decoration: self-coloured heart-shaped leaf motif with hemispherical patterns (Fig. 6.38)

12. Brigetio/Szőny-Vásártér: Inv. no. 2001.-C/-D18.22.31, fragment of a cylindrical beaker, greenish; decoration: self-coloured looped serpentiform V-shaped trails with slashed surface (Fig. 5.15)

13. Brigetio/Szőny-Vásártér: Inv. no. 2005.H11.32.10, fragment of a cylindrical beaker, colourless; decoration: self-coloured looped serpentiform trails with slashed surface and rounded curved end (Fig. 6.31, Fig. 8.50)

14. Brigetio/Szőny-Vásártér: Inv. no. 1992.1.79.28, fragment of a cylindrical beaker, colourless; decoration: self-coloured looped serpentiform trails with slashed surface (Fig. 5.23)

15. Brigetio/Szőny-Vásártér: Inv. no. 1992.05.037.429, fragment of a cylindrical beaker, colourless; decoration: self-coloured looped serpentiform trails with slashed surface and rounded curved end (Fig. 6.33)

16. Brigetio/Szőny-Vásártér: Inv. no. 1992.03.228.244, fragment of a cylindrical beaker, colourless, tapering lower body, with globular knob on stem (Fig. 5.27)

17. Brigetio/Szőny-Vásártér: Inv. no. 1992.01.56.140, fragment of a cylindrical beaker with stem and foot, grass green, tapering lower body, selfcoloured tendril decoration, thin horizontal trail with slashed surface on the base and U-shaped vertical trails with slashed surface (Fig. 7.46)

18. Brigetio/Szőny-Vásártér: Inv. no. 2015.K15.121.2, fragment of a cylindrical beaker, colourless, tendril decoration, slender opaque white looped serpentiform trail (Fig. 8.54)

19. Brigetio/Szőny-Vásártér: Inv. no. 2012.L13-L14.076.3-4, fragment of a cylindrical beaker, colourless, self-coloured slender tendril decoration (Fig. 6.43, Fig. 8.57)

20. Brigetio/Szőny-Vásártér: Inv. no. 2012.M13-14.061.7, fragment of a cylindrical beaker, colourless, self-coloured slender tendril decoration (Fig. 8.58)

21. Brigetio/Szőny-Vásártér: Inv. no. 2012.M13-14.009.23, fragment of a cylindrical beaker, colourless; decoration: self-coloured heart-shaped leaf motif with hemispherical patterns (Fig. 8.59)

22. Brigetio/Szőny-Vásártér: Inv. no. 2012.M13-14.061.6, fragment of a cylindrical beaker, colourless; decoration: self-coloured looped serpentiform trails with slashed surface and rounded curved end (Fig. 8.60)

23. Brigetio/Szőny-Vásártér: Inv. no. 2011.L15-L16.094.10, fragment of a cylindrical beaker, colourless, base fragment (Fig. 8.48)

24. Brigetio/Szőny-Vásártér: Inv. no. 2010.K15.121.2, fragment of cylindrical a beaker, colourless; decoration: self-coloured looped serpentiform trails (Fig. 8.49)

25. Brigetio/Vásártér 13: Inv. no. 2006.V13.213.1, fragment of a cylindrical beaker with stem and foot, colourless; decoration: looped serpentiform opaque turquoise trails (Fig. 5.16)

26. Brigetio/Vásártér 13: Inv. no. 2006.V13.213.2, fragment of a cylindrical beaker, colourless; decoration: looped serpentiform opaque yellow trails with slashed surface (Fig. 5.20)

27. Brigetio/Vásártér 13: Inv. no. 2006.V13.213.3, fragment of a cylindrical beaker, colourless; decoration: self-coloured looped serpentiform curved trails (Fig. 5.19)

28. Brigetio/Vásártér 13: Inv. no. 2006.V13.213.4, fragment of a cylindrical beaker, colourless; decoration: self-coloured looped serpentiform vertical trails with slashed surface (Fig. 5.17)

29. Brigetio/Vásártér 13: Inv. no. 2006.V13. A4.100, fragment of a cylindrical beaker, colourless; decoration: self-coloured and opaque turquoise vertical V-shaped trails (Fig. 4.10)

30. Brigetio/Vásártér 13: Inv. no. 2006.V13.133.111, fragment of a cylindrical beaker, colourless; decoration: opaque turquoise vertical trails (Fig. 6.42)

31. Brigetio/Vásártér 13: Inv. no. 2006.V13.203.1, fragment of a cylindrical beaker, colourless; decoration: opaque yellow curved trails (Fig. 5.25)

32. Brigetio/Vásártér 13: Inv. no. 2006.V13.203.2, fragment of a cylindrical beaker, colourless; decoration: self-coloured trails (Fig. 6.29)

Acta Archaeologica Academiae Scientiarum Hungaricae 70, 2019 
33. Brigetio/Vásártér 13: Inv. no. 2006.V13.203.3, fragment of a cylindrical beaker, colourless; decoration: self-coloured trails with slashed surface (Fig. 6.29)

34. Brigetio/Vásártér 13: Inv. no. 2006.V13.218.1, fragment of a cylindrical beaker, colourless; decoration: self-coloured trails with slashed surface (Fig. 6.39)

35. Brigetio/Vásártér 13: Inv. no. 2006.V13.218.2, fragment of a cylindrical beaker with stem and foot, colourless; decoration: self-coloured trails with slashed surface folded over each other (Fig. 6.40)

36. Brigetio/Vásártér 13: Inv. no. 2006.V13.218.3, fragment of a cylindrical beaker, colourless, rim fragment, fire-rounded edge; decoration: horizontal opaque turquoise trail below the rim (Fig. 5.18)

37. Brigetio/Vásártér 13: Inv. no. 2006.V13.218.4, fragment of a cylindrical beaker, colourless; decoration: opaque yellow curved trail (Fig. 5.24)

38. Brigetio/Vásártér 13: Inv. no. 2006.V13.218.5, fragment of a cylindrical beaker, colourless; decoration: self-coloured trails with slashed surface and L-shaped trail (Fig. 5.14)

39. Brigetio/Vásártér 13: Inv. no. 2006.V13.135.58, fragment of a cylindrical beaker, colourless; decoration: part of an opaque dark blue bird figure with chequered design (Fig. 4.9)

40. Brigetio/Vásártér 13: Inv. no. 2006.V13.185.1, fragment of a cylindrical beaker with stem and foot, colourless; decoration: opaque yellow leaf motif with curved end and slashed surface (Fig. 4.11, Fig. 6.28)

41. Brigetio/Vásártér 13: Inv. no. 2006.V13.177.1, fragment of a cylindrical beaker, colourless; decoration: self-coloured curved trail (Fig. 6.41)

42. Brigetio/Vásártér 13: Inv. no. 2006.V13.218.6-7, fragment of a cylindrical beaker, colourless; decoration: self-coloured trails with slashed surface (Fig. 6.30)

43. Brigetio/Vásártér 13: Inv. no. 2006.V13.199.1, fragment of a cylindrical beaker, colourless; decoration: opaque turquoise and white trail (Fig. 6.44)

44. Brigetio/Vásártér 13: Inv. no. 2006.V13.185.2, fragment of a cylindrical beaker, colourless; decoration: self-coloured curved trail with chequered design (Fig. 8.52)

45. Brigetio/Vásártér 13: Inv. no. 2006.V13.185.3, fragment of a cylindrical beaker, colourless; decoration: opaque blue bird-shaped motif with hemispherical patterns (Fig. 4.9)

\section{REFERENCES}

ARVELLIER-DULONG-SENNEQUIERVANPEENE 2003

BARAG 1967

BARKÓCZI 1981

BARKÓCZI 1988

BORHY 2014

BORHY-BARTUS et al. 2012

BORHY-BARTUS et al. 2014

CoOL-Price 1995

CotTAM-Price 1998

DÉvaI 2015

DÉVAI-GELENCSÉR 2012

DoBOSI-BORHY 2011

DoBosi 2019

FREMERSDORF 1959
= V. Arvellier-Dulong-G. Sennequuier-N. Vanpeene: Verreries du Nord-Ouest de la Gaule : Productions et importations. In: Echanges et commerce du verre dans le monde antique. Actes du colloque de 1'AFAV à Aix-en-Provence et Marseille (7-9 juin 2001). Dir.: D. Foy, M.-D. Nenna. Monographies instrumentum 24. Montagnac 2003, 147-160.

= D. BARAG: "Flower and Bird" and snake-thread glass vessels. Annales AIHV 4 (1967) 55-66.

= L. BARKóCZI: Kelche aus Pannonien mit Fadenauflage und Gravierung. ActaArchHung 33 (1981) $35-70$.

= L. BARKóCZI: Pannonische Glasfunde in Ungarn. StudArch 9. Budapest 1988.

= L. BorHY: Bibliography of the excavations in Brigetio (1992-2014). DissArch Ser. $3 / 2$ (2014) 565-580.

= D. BARTus-L. Borhy-K. DÉvaI-Z. KIS-A. NAGY-N. SEY-E. SZÁMAdó-Zs. SzóRÁdI-I. VIdA: Jelentés a Komárom-Szőny, Vásártéren 2011-ben folytatott régészeti feltárások eredményeiről (Bericht über die Ergebnisse der in Brigetio (FO: Komárom-Szőny, Vásártér) im Jahre 2011 geführten archäologischen Ausgrabungen). KEMMK 18 (2012) 7-39.

= D. Bartus-L. Borhy-G. Delbó-K. Dévai-Z. Kis-A. Nagy-N. Sey-E. SzÁmadó-Zs. SzórádiI. VIDA, Jelentés a Komárom-Szőny, Vásártéren 2012-ben folytatott régészeti feltárások eredményeiről (Bericht über die Ergebnisse der in Brigetio (FO: Komárom-Szőny, Vásártér) im Jahre 2012 geführten archäologischen Ausgrabungen). KEMMK 20 (2014) 33-90.

= H. M. E. Cool-J. Price: Roman Vessel Glass from Excavations in Colchester, 1971-1985. ColchArchRep 8. Colchester 1995.

= S. CotTAM-J. Price: Romano-British Glass Vessels: A handbook. York 1998

$=\mathrm{K}$. DÉvAI: The secondary glass workshop in the Civil Town of Brigetio. DissArch Ser. $3 / 3$ (2015) 83-104.

= K. DÉVAI-Á. GELENCSÉR: Római kori lakóépület és üvegyártó mühely Brigetióból (The secondary glass workshop in civil town of Brigetio). KEMMK 18 (2012) 59-93.

= L. Dobosi-L. Borhy: The municipium of Brigetio. Roman houses at Komárom/Szőny-Vásártér. Architecture 42/2 (2011) 3-10.

$=\mathrm{L}$. Doвosi: Brigetio around the time of Hadrian - The early history of the civil town. In: Hadrianus MCM - History of an Ancient Career. International Archaeological Conference, 7-9. November, 2017. Aquincum Nostrum II/9. Ed.: O. Láng. Budapest 2019. (in press)

= F. FREMERSDORF: Römische Gläser mit Fadenauflage in Köln (Schlangenfadengläser und Verwandtes). Die Denkmäler des römischen Köln 5. Köln 1959.

Acta Archaeologica Academiae Scientiarum Hungaricae 70, 2019 
HANUT 2003

HARDEN 1934

ISINGS 1957

KISA 1908

KISS 2006

KISS 2007

LAZAR 2003

MARIËN 1984

Mócsy 1974

SAKL-OBERTAHLER-TARCSAY 2001

STREN 2001

VISY 1974
$=$ F. HANUT: La vaisselle à décor vermiculaire en Belgique $:$ chronologie et utilisation. In: ATUATUVA.

1.: Roman Glass in Germania Inferior. Interregional comparisons and recent results. Eds:

G. Creemers, B. Demarsin, P. Cosyns. Tongeren 2006, 114-124.

= D. B. HARDEN: Snake-thread glasses found in the East. JGS 24 (1934) 50-55.

= C. IsINGS: Roman Glass. Groeningen-Djakarta 1957.

= A. KisA: Das Glas im Altertume. I-III. Bonn 1908.

= P. KIss: Urnák, hamvak, leletek. Régészeti feltárás Savaria északi temetőjében [Urns, ashes, findings. Excavation in the northern cemetery of Savaria]. Ókor 2006, 93-96.

= P. Kiss: Leletek Savaria északi temetőjéből [Findings from the northern cemetery of Savaria]. Szombathely 2007.

= I. LAZAR: Rimsko Steklo Slovenije - The Roman Glass of Slovenia. Ljubljana 2003.

= M.-E. MARIËN: Romeins glaswerk met kronkelende glasdraden uit Belgie [Roman glassware with applied glass trails from Belgium]. Bulletin de Musées royaux d'Art et d'Histoire 55 (1984) 63-74.

= A. Mócsy: Pannonia and Upper Moesia. A History of the Middle Danube. Provinces of the Roman Empire. London-Boston 1974.

= S. SAKL-Oberthaler-K. TARCSAY: Römische Glasformen aus Wien. Fundort Wien. Berichte zur Archäologie 4 (2001) 78-112.

= E. M. STERN: Römisches, byzantinisches und frühmittelalterliches Glas. Sammlung Ernesto Wolf. 10 v. Chr.-700 n. Chr. Ostfildern 2001.

= Zs. VISY: Archäologische Forschungen im Jahre 1973. ArchÉrt 101 (1974) 316

Open Access. This is an open-access article distributed under the terms of the Creative Commons Attribution 4.0 International License (https:// creativecommons.org/licenses/by/4.0), which permits unrestricted use, distribution, and reproduction in any medium, provided the original author and source are credited, a link to the CC License is provided, and changes - if any - are indicated. (SID_1)

Acta Archaeologica Academiae Scientiarum Hungaricae 70, 2019 